\title{
Building Cooperation Interpersonal Skill in Physical Education Lessons Through Traditional Game
}

\author{
Sasminta Christina Yuli Hartati \\ Faculty of Sport Science \\ Universitas Negeri Surabaya \\ Surabaya, Indonesia \\ sasmintahartati@unesa.ac.id
}

\author{
Anung Priambodo \\ Faculty of Sport Science \\ Universitas Negeri Surabaya \\ Surabaya, Indonesia \\ anungpriambodo@unesa.ac.id
}

\author{
Bernard Djawa \\ Faculty of Sport Science \\ Universitas Negeri Surabaya \\ Surabaya, Indonesia \\ bernarddjawa@unesa.ac.id
}

\author{
Bayu Budi Prakoso \\ Faculty of Sport Science \\ Universitas Negeri Surabaya \\ Surabaya, Indonesia \\ bayuprakoso@unesa.ac.id
}

\begin{abstract}
Cooperation as interpersonal skill is one of the four important competencies that must be possessed by learners to be able to lead a successful life in the 21st century. Therefore, teachers, who are usually only concerned with assisting students to meet certain hard-skill qualifications, are now also required to include cooperation in their objective. Therefore, teachers, including physical education teachers, must be able to develop teaching materials to meet such demands and all the while promoting physical activities. Games can become a reliable teaching resource to increase learners' involvement in learning and to create a cooperative learning environment. Hence, this article is focused in describing the results of the teacher's competence advancement activities as an effort to develop game as a resource to teach cooperation. A total of 23 games were selected to be played by 33 prospective $P E$ teachers and 20 experienced PE teachers at elementary level to increase teacher's competence in the development of game as teaching resource. Assessment results stated the 23 games were appropriate $\mathbf{( 7 7 . 5 \% )}$ to create an environment in which learning process that promotes cooperation to students could take place. In addition, score of teacher knowledge of game as teaching resource is $59.8 \%$ (adequate). Thus, trainings in developing game as a resource to teach cooperation in learning for Elementary School Students is necessary, specifically for elementary school physical education teachers.
\end{abstract}

Keywords- interpersonal skill, emotion regulation, cooperation, physical education lessons, traditional game

\section{INTRODUCTION}

Indonesia's education goals have been formulated at least through legislation and / or products in the form of government regulations which regulates education. The arrangement of education in schools is systematically regulated by the government through the national curriculum which is the realization of the full authority of the government in regulating national education [1]. With the help of experts from universities, the government uses its authority to compile the national curriculum. Universities are considered as a strategic institution to contribute in developing national education.

In 2012 and 2016 in its convention, ALPTKNI (Association of Higher Education Institutions of State Education of Indonesia), declared efforts to improve the quality of education to prepare learners for Indonesia Golden Generation 2045. Indonesia Golden Generation 2045 is a
Pancasila-spirited Indonesian who has global and futuristic skills, who is able to utilize science and technology based on cultural values and nationalism, and give benefit to mankind [2]. Therefore, it can be concluded that Indonesia Golden Generation 2045 must have good character and will most likely be realized through the education process.

Thus, along with preparing learners to lead a character human, education in Indonesia is also directed to educate students to master the 21st century interpersonal skills competence, namely collaboration, communication, critical thinking, and creative [3]. These four characters are considered important to be mastered so that learners are able to survive and compete in life in the 21 st century.

Character education in Indonesia has long been echoed through the school curriculum. In the composition of the education curriculum in Indonesia, Physical Education (PE) becomes a compulsory subject in the curriculum structure of the school [4] which focuses on character education through the internalization of values of motion and sport activities [1]. Movement skills and sport are believed to be a suitable tool for forming interpersonal skills of learners [5].

PE learning is almost always done in groups facing tactical problems in sports games, and requires students to obey the rules. Thus, this activity is believed to be a suitable way for the process of habitually behaving well for building positive interpersonal skills. Furthermore, students who participate in cooperative learning programs designed specifically in accordance with the needs of students proved to improve social skills and attitude that prioritizes cooperation [6].

In addition, PE is also the most strategic vehicle for promoting an active lifestyle in school [7]. Positive impact of active life behavior that is avoid disease, heighten life expectancy, and reduce excess weight [8]. For that, PE can be called as the ideal subjects in preparing the Indonesia Golden Generation 2045. Because strengthening the character alone is not enough without being equipped with excellent physical condition. Learning PE has both of these things, namely strengthening the character of PE and providing physical education to a healthy man avoid the pain through active life behavior. The current state of illness is at an alarming point, especially pain due to passive living behavior. WHO reports that inactive living habits are the four main factors of death in the world [9]. For that, Indonesia needs to encourage its 
citizens to change the passive lifestyle towards the more active life. According to the results of a national survey by the Ministry of Youth and Sports of the Republic of Indonesia, shows that only $22 \%$ of Indonesians who exercise and the number is decreasing daily [8].

Passive lifestyle problems will be more difficult to address if $\mathrm{PE}$ fails in providing learning to familiarize life active to school-aged children. School-age children tend to spend their free time watching television, playing video games, and playing computer [10]. Children today tend to prefer modernlooking games like video games, play-station, and online games compared to traditional games with terms of character and physical activity [11]. No doubt that children now tend to be curious and challenged with the modern game. So much of their free time is spent on playing the game. If this is left unchecked, the adequacy of child's motion will not be fulfilled.

To help overcome the above challenges, PE learning, especially at the elementary level, should be complemented by a variety of simple and / or traditional game activities that can help instill good interpersonal character while promoting an active lifestyle in its teaching materials [12]. The selection of game types to be taught to learners should match the child's development. Thus, the desire to move and the needs of student movement can be fulfilled and students' learning needs can be facilitated.

Learning that can facilitate learners to learn is quality learning. Quality learning will only be realized if done by a qualified teacher who becomes the main key [13, 14, 15]. Therefore, in order to fulfill the existing demands, the development of teacher competence so that the educational process especially in the schooling path becomes important to be done [16]. Development of teacher competence is needed to be able to develop the teaching materials in the form of simple and traditional games performed in accordance with the development of children.

This article is part of the results of teacher competence development in developing teaching materials in the form of simple and traditional games through the community of teachers PE in elementary school. The development of teacher competence through the community is felt to be effective because the teacher community is the main place for teacher competence development. There are five important things that make the teacher community the main place of teacher competence development, namely: (1) supportive and shared leadership; (2) shared values, vision, and goals; (3) collective learning and application; (4) shared individual practice; and (5) supportive conditions (both physical and human) [17]. There are 23 types of games given to the teacher community during teacher competency development activities. Simple and traditional game material given to the community, directed to a game that affects the character of cooperation for learners according to the literature. For that, need to be assessed gamegame as the material in forming cooperation learners through teacher opinion. In addition, through this teacher's competencybuilding activities, teachers' knowledge of simple and traditional games will be explained.

\section{MATERIALS AND METHODS}

\section{A. Participant}

This article is part of the results from teacher competence development activities in developing teaching materials in the form of simple and traditional games. This activity involves prospective PE teachers, PE teachers, and researchers (lecturers).

A total of 33 prospective PE teachers and 20 PE teachers participated in this study. Both prospective teachers and teachers of PE follow voluntary activities to develop competence as prospective teachers and teachers of PE.

\section{B. Procedure}

The activity begins with the preparation of a research team in recruiting prospective $\mathrm{PE}$ teachers who volunteer to participate in the event. The research team trained prospective PE teachers to practice 23 types of games as teaching materials, which are: (1) Mencari kelompok; (2) Bersatu kita teguh; (3) Menjala ikan; (4) Hitam hijau; (5) Banjir, gempa, dan tsunami; (6) Rajawali mengejar anak ayam; (7) Bermain angka (ganjil, genap); (8) Karapan sapi; (9) Tom and Jerry; (10) Beteng-betengan; (11) Gobak Sodor; (12) Estafet; (13) Lempar kejar bola; (14) Berburu binatang; (15) Pulau impian; (16) Mencuri harta karun; (17) Kotak Pintar; (18) Boy-boy-an; (19) Tongkat jalan; (20) Tee ball; (21) Kasti; (22) Kippers; dan (23) Slagball.

The development of PE teacher competence is carried out in training activities starting from the giving of material in the form of the importance of fulfilling the physical activity of learners and the character formation of learners, and the process of developing simple and traditional game material. The activity continued with the practice of 23 games as training materials divided into 3 practice sessions. Once practiced, prospective PE teachers and PE teachers are welcome to try and develop the games that have been practiced.

\section{Instrumentation}

Two instruments are used in obtaining game conformity data in learning the cooperation of learners and knowledge of PE teachers on the development of simple and traditional game materials. Two instruments used are closed questionnaire developed using Likert scale.

The first instrument used to determine the suitability of simple and traditional games to teaching cooperation to learners. It is an instrument that collects teacher assessments based on teachers' perceptions of the 23 types of games practiced by potential PE teachers. Questionnaire is closed by using likert scale from inappropriate to very suitable.

The second instrument is used to find out the teacher's knowledge in the development of simple and traditional games. In addition, this instrument comes with the experience of teachers in making use of simple and traditional games in learning events. This instrument is developed based on teacher's knowledge. Likert scale used ranging from not knowing to ever teach. 


\section{Data analysis}

Data analysis used is descriptive statistic and percentage.

\section{RESULTS AND DISCUSSION}

The results explain three things, namely: (1) knowledge of PE teachers on simple and traditional game materials; (2) the appropriateness of simple and traditional game material to promote cooperation to learners; and (3) experience of PE teachers in providing simple and traditional game materials in learning. The value of knowledge of PE teachers about simple and traditional game materials get the value of 59.8 included in the category enough. Meanwhile, according to PE teachers, the value of the conformity of simple and traditional game materials to teach cooperation to learners of 77.5 included in the appropriate category (see table 1).

TABLE I. RESUlts OF TEACHER KNOWLEDGE AsSESSMENT OF GAME MATERIALS AND THEIR CONFORMITY TO COOPERATE LEARNING TO LEARNERS.

\begin{tabular}{|c|l|l|l|}
\hline No. & Assessment component & Value & Category \\
\hline 1 & $\begin{array}{l}\text { PE teacher's knowledge of simple and } \\
\text { traditional games }\end{array}$ & 59.8 & Adequate \\
\hline 2 & $\begin{array}{l}\text { The suitability of simple and } \\
\text { traditional games to establish } \\
\text { cooperation }\end{array}$ & 77.5 & Suitable \\
\hline
\end{tabular}

Furthermore, $39.9 \%$ of PE teachers claimed to have never used simple and traditional game material, as many as $27.5 \%$ admitted to using game material for warming up, $29.6 \%$ claimed to have used game material for the main lesson, and $3.0 \%$ admitted to using game material for cooling down (see table 2).

TABLE II. EXPERIENCE OF PE TEACHERS IN USING SIMPLE AND TRADITIONAL GAME MATERIALS IN LEARNING.

\begin{tabular}{|c|l|c|}
\hline No. & \multicolumn{1}{|c|}{ Experience of PE teachers } & Percentage \\
\hline 1 & Never used & $39.9 \%$ \\
\hline 2 & Using game material for warming up & $27.5 \%$ \\
\hline 3 & Using game material for the main lesson & $29.6 \%$ \\
\hline 4 & Using game material for cooling down & $3.0 \%$ \\
\hline
\end{tabular}

Teachers' knowledge of the subject areas of teaching is one of the measures of professional competence of teachers [18]. The development of competence of prospective teachers while studying in college becomes the right time to strengthen student competence to become a qualified teacher. Unfortunately, universities are currently underprivileged to prepare prospective teachers to become good teachers [19]. Therefore, the development of teacher competence is not sufficient only in universities when prospective teachers are studying, but it is necessary to develop sustainable teacher competence as they become teachers.

Ideally, teacher competence development is the responsibility of every teacher. However, the willingness of teachers to develop themselves to improve teacher competence decreases with the longer teaching time [20]. For that, there needs to be collaboration between various institutions to support and encourage teachers to be aware of the needs of self-development in a sustainable manner. Continued development of teacher competence needs to be supported by good collaboration from governments, universities, and schools [21]. The government provides encouragement in the form of various certification programs with high incentives, universities as a place of science novelty and innovation in learning, while schools through the principal must provide assistance to teachers in learning innovation [16].

Based on the results of the knowledge assessment (see table 1), it illustrates how efforts to improve teacher competence still need to be done. Collaboration of government, college, and school becomes important to do. This training is a reflection that teacher's knowledge of game teaching materials that are at the core of the material in elementary school is not enough for teachers to create good learning.

Unfortunately, these training activities are still not able to provide the maximum to provide training materials to teaching cooperation to learners (see table 1). According to the teacher's perception, there is still training material to develop teacher competence can't be used to teaching cooperation to learners. Games that are not suited to teaching cooperation to learners is an individual game. As a result, in the learning process there is no process to familiarize learners in cooperation. The learning process for improving character-cooperation is a learning that is able to provide a learning environment in which there are good character habits [1].

Unfortunately, these training activities are still not able to provide the maximum to provide training materials to teaching cooperation to learners (see table 1). According to the teacher's perception, there is still training material to develop teacher competence can't be used to teaching cooperation to learners. Games that are not suited to teaching cooperation to learners is an individual game. As a result, in the learning process there is no process to familiarize learners in cooperation. The learning process for improving character-cooperation is a learning that is able to provide a learning environment in which there are good character habits [1].

\section{CONCLUSIONS}

Looking at the results of PE teacher knowledge assessment of simple and traditional game materials, there is an indication that the existence of PE teacher competency development activities is increasingly needed. Of course, the development of teacher competence will involve the government through its rules, the college through its novelty and scientific innovation, and the school through the assistance of the principal. The existence of material that is considered not suitable for teaching cooperation to learners indicates that is still needed for the study literature and even discussion with experts related material development of teacher competence. So game materials can have an impact on teacher knowledge and skills in developing game materials that can create a learning environment that familiarizes cooperation activities and fulfillment of physical activities of learners. 


\section{ACKNOWLEDGMENT}

The writer would like to thank the Dean of the Faculty of Sport Science of Universitas Negeri Surabaya who has supported the research. Special thanks for Muhammad Arsyad, Ph.D. Hasanuddin University, Makassar who has provided input in the clinical manuscript event so that this article can be better.

\section{REFERENCES}

[1] Suroto, "Peran PJOK dalam Membangun Karakter Siswa," in Menuju Generasi Yang Sehat dan Berprestasi Dalam Bidang Olahraga Melalui Pendidikan Karakter Berlandaskan Aswaja, 2017.

[2] Anonymous, "Konvensi Nasional Pendidikan Indonesia: KONASPI VIII 2016," 2016. [Online]. Available: http://seminars.unj.ac.id/konaspi/. [Accessed: 09-Jan-2017].

[3] Suroto, "Inovation Teaching Method for Physical Education Teacher in Indonesia," in Proceeding 2nd International Conference of Sport Science, 2017, pp. 94-107.

[4] Republic of Indonesia, Undang-Undang Republik Indonesia Nomor 20 tahun 2003 tentang Sistem Pendidikan Nasional, no. 20. 2003.

[5] M. Austin, "Sport as a Moral Practice: An Aristotelian Approach," R. Inst. Philos. Suppl., vol. 73, no. 2007, pp. 29-43, 2013.

[6] M. Goudas and E. Magotsiou, "The Effects of a Cooperative Physical Education Program on Students' Social Skills," J. Appl. Sport Psychol., vol. 21, no. 3, pp. 356-364, 2009.

[7] J. F. Sallis, T. L. McKenzie, J. E. Alcaraz, B. Kolody, N. Faucette, and M. F. Hovell, "The Fffects of a 2-year Physical Education Program (SPARK) on Physical Activity and Fitness in Elementary School Students," Am. J. Public Health, vol. 87, no. 8, pp. 1328-1334, 1997.

[8] Setyorini, Suroto, and N. Indahwati, "First Grade Primary School Students' Physical Activity Level on Physical Education Subject through Live Life Well at School Program," IOP Conf. Ser. Mater. Sci. Eng., vol. 180, no. 12178, pp. 1-6, 2017.

[9] World Health Organization, Global Recommendations on Physical Activity for Health. Switzerland: WHO Press, 2010.
[10] R. B. Woods, Social Issues in Sport. USA: Human Kinetics Publishers, Inc., 2007.

[11] H. Nur, "Membangun Karakter Anak melalui Permainan Anak Tradisional,” J. Pendidik. Karakter, vol. 3, no. 1, pp. 87-94, 2013.

[12] Menteri Pendidikan dan Kebudayaan Republik Indonesia, Permendikbud RI No. 24 Tahun 2016 tentang Kompetensi Inti dan Kompetensi Dasar Pelajaran Pada Kurikulum 2013 Pada Pendidikan Dasar dan Pendidikan Menengah. 2016.

[13] Ganefri, "Kolaborasi Strategi Pemberdayaan Lintas Institusi dan Participatory Management Menuju Sistem Rekrutmen dan Distribusi Guru yang Proporsional-Efektif di Indonesia," in Konvensi Nasional Pendidikan Indonesia (KONASPI) VIII Tahun 2016, 2016, pp. 35-40.

[14] Djaali, "Kurikulum dan Sistem Pembelajaran di LPTK," in Konvensi Nasional Pendidikan Indonesia (KONASPI) VIII Tahun 2016, 2016, pp. $1-12$.

[15] A. I. Şen, "Effects of Peer Teaching and Microteaching on Teaching Skills of Pre-Service Physics Teachers," Egit. ve Bilim, vol. 35, no. 155, pp. 78-88, 2010.

[16] Suroto, "Peran Sekolah dan Perguruan Tinggi dalam Mewujudkan Guru PJOK Profesional yang Pembelajar," in Konvensi Nasional Pendidikan Indonesia (KONASPI) VIII Tahun 2016, 2016, pp. 1425-1430.

[17] K. Vangrieken, C. Meredith, T. Packer, and E. Kyndt, "Teacher Communities as a Context for Professional Development: A Systematic Review," Teach. Teach. Educ., vol. 61, pp. 47-59, 2017.

[18] Suroto, F. D. Khory, V. C. Dinatta, and A. Priambodo, "Core Competency Measurement Model for Prospective Physical Education Teacher," IOP Conf. Ser. Mater. Sci. Eng., vol. 180, no. 12181, pp. 1-6, 2017.

[19] G. Hill and K. L. Brodin, "Physical Education Teachers' Perceptions of the Adequacy of University Coursework in Preparation for Teaching.," Phys. Educ., vol. 61, no. 2, pp. 75-87, 2004.

[20] A. Maksum, "Kualitas Guru Pendidikan Jasmani di Sekolah: Antara Harapan dan Kenyataan," no. 3, pp. 1-32, 2010.

[21] R. S. Nagovitsyn, S. Y. Senator, E. B. Maximova, N. V. Neverova, and E. I. Sokolnikova, "Continuous professional education of teachers of physical education with the additional qualification in the field of foreign languages on the basis of competency-based approach," J. Phys. Educ. Sport, vol. 17, no. 4, pp. 2170-2178, 2017. 